\title{
Surat Berharga Syariah Negara Berbasis Proyek Pada Kementerian Agama: Alternatif Pembiayaan Infrastruktur Pemerintah
}

\author{
Nurbiyanto \\ Politeknik Keuangan Negara STAN \\ nurbiyanto@pknstan.ac.id \\ Yanuar Pribadi \\ Politeknik Keuangan Negara STAN \\ yanuar.pribadi@pknstan.ac.id
}

\begin{abstract}
Abstrak Penelitian ini bertujuan untuk mengevaluasi pelaksanaan pembangunan infrastruktur yang dibiayai melalui Surat Berharga Syariah Negara pada Kementerian Agama. Pembangunan infrastruktur yang akan terus berlangsung beberapa tahun ke depan, membutuhkan sumber pendanaan yang sangat besar. Kendala yang memengaruhi pelaksanaan proyek berdasarkan hasil penelitian ini meliputi permasalahan pada saat lelang, kontraktor yang kurang memenuhi kompetensi, minimnya akurasi perencanaan dan evaluasi yang belum efektif. Meskipun permasalahan tersebut menjadi kendala dalam pelaksanaan proyek, namun Project Based Sukuk merupakan alternatif sumber pendanaan yang tepat untuk membiayai pembangunan proyek-proyek pada Kementerian/Lembaga. Pasar keuangan syariah domestik yang masih terbuka menjadi keuntungan dalam pengembangan pasar keuangan Surat Berharga Syariah Negara sehingga instrumen Surat Berharga Syariah Negara terutama skema Project Based Sukuk merupakan alternatif pembiayaan yang potensial untuk terus dikembangkan oleh pemerintah.
\end{abstract}

Kata Kunci Surat Berharga Negara, Sukuk, Proyek Infrastruktur Pemerintah

\section{PENDAHULUAN}

Indonesia menganut sistem ekonomi ekspansif untuk mendorong kegiatan perekonomian. Namun, keterbatasan sumber pendapatan negara menyebabkan terjadinya defisit anggaran dalam struktur Anggaran Pendapatan dan Belanja Negara (APBN). Pembiayaan anggaran dalam struktur APBN merupakan konsekuensi dari sistem anggaran defisit. Pembiayaan Anggaran adalah setiap penerimaan yang perlu dibayar kembali, penerimaan kembali atas pengeluaran tahun-tahun anggaran sebelumnya, pengeluaran kembali atas penerimaan tahun-tahun anggaran sebelumnya, penggunaan saldo anggaran lebih, dan/atau pengeluaran yang akan diterima kembali, baik pada tahun anggaran yang bersangkutan maupun tahun-tahun anggaran berikutnya. Pembiayaan Anggaran ini meliputi Pembiayaan Utang, Pembiayaan Investasi, Pemberian Pinjaman (ke BUMN/BUMD/ Pemda), dan Pembiayaan Lainnya. Pembiayaan Utang merupakan 
pembiayaan yang didapatkan melalui pinjaman dan Surat Berharga Negara (SBN). Pinjaman dapat bersumber dari Dalam Negeri dan Luar Negeri, sedangkan SBN berasal dari Surat Utang Negara (SUN) dan Surat Berharga Syariah Negara (SBSN).

Pemerintah saat ini fokus di sektor pembangunan infrastruktur untuk mengejar ketertinggalan dari negara lain, membuka akses untuk mengurangi ketimpangan antardaerah, serta mempersingkat waktu distribusi. Hal itu menyebabkan kebutuhan pendanaan pemerintah meningkat sangat signifikan untuk membiayai pembangunan proyek-proyek infrastruktur seperti jalan, jembatan, pelabuhan laut/udara, dan lain-lain. Keterbatasan sumber pendapatan untuk memenuhi kebutuhan belanja membuat utang masih menjadi alternatif untuk membiayai pembangunan.

Secara umum, utang yang bersumber dari SBN digunakan untuk menutupi kekurangan dana pemerintah sehingga pembiayaan tersebut bersifat umum (general financing). SBN berbeda dengan pinjaman yang secara langsung digunakan untuk membiayai proyek/kegiatan tertentu. Sifat SBN yang digunakan untuk membiayai defisit secara umum, sering menimbulkan pertanyaan mengenai pemanfaatannya. Hal inilah yang membuat utang menjadi isu sensitif dan seringkali menjadi pro dan kontra yang menimbulkan perdebatan publik.

Penelitian ini menganalisis mengenai bagaimana peran utang yang digunakan secara langsung untuk membiayai proyek terutama yang berbentuk Project Based Sukuk (PBS), mengidentifikasi kendala-kendala yang terjadi di lapangan sehingga menyebabkan pembiayaan melalui PBS masih belum dilakukan secara optimal.

Penelitian mengenai Sukuk telah dilakukan dan memberikan kesimpulan bahwa efek multiplier yang signifikan dari pembiayaan melalui sukuk akan diperoleh melalui pembangunan infrastruktur, pembangunan sektor ekonomi yang bersifat padat karya, dan optimalisasi potensi daerah (Beik, 2011). Dalam pembangunan infrastruktur, SBSN khususnya Project Based Sukuk merupakan instrumen yang sangat potensial untuk pembangunan infrastruktur (Nopijantoro, 2017). Sedangkan dari sisi investor, SBSN dinilai sebagai investasi yang aman karena menggunakan aset yang dijaminkan (underlying asset) sehingga risiko gagal bayar/default sangat kecil terjadi (Nasrullah, 2015). Hal ini merupakan sebuah keuntungan sehingga pembiayaan melalui SBSN masih sangat terbuka untuk dikembangkan.

\section{LANDASAN TEORI}

\section{A. Utang Sebagai Instrumen Kebijakan Pendorong Pertumbuhan Ekonomi}

Kebijakan pemerintah yang dituangkan dalam APBN juga dapat digunakan untuk memengaruhi perekonomian. Menurut Teori Keynes, Pemerintah memiliki kewenangan untuk memengaruhi perekonomian dengan melakukan intervensi kebijakan ekonomi (Skousen, 2016). Kebijakan ekonomi ekspansif berfungsi untuk menggerakkan perekonomian dan meningkatkan pertumbuhan. Melalui kebijakan anggaran yang ekspansif, belanja negara lebih besar daripada pendapatan negara, sehingga terdapat selisih kurang antara pendapatan dengan belanja yang disebut dengan defisit. Keterbatasan sumber pendapatan negara menyebabkan utang masih menjadi salah satu alternatif dan tumpuan dalam membiayai belanja negara.

Permasalahan yang dialami oleh masing-masing negara dapat memengaruhi defisit anggaran. Sebagian besar penyebab defisit ialah kebutuhan untuk meningkatkan 
perekonomian. Akan tetapi kebutuhan tersebut tidak diikuti dengan kemampuan di sisi pendapatan terutama dari sektor pajak. Lebih jauh lagi, suatu negara cenderung tidak menaikkan penerimaan pajak untuk menjaga kestabilan perekonomian. Akhirnya, kebijakan untuk tidak meningkatkan pungutan pajak membuat suatu negara cenderung untuk meningkatkan utangnya (Barro, 1989).

Kebijakan defisit suatu negara tentu memiliki risiko. Efek negatif kebijakan defisit dapat berupa beban utang yang harus ditanggung pemerintah. Defisit anggaran karena kebijakan fiskal dapat meningkatkan ekonomi pada jangka pendek, namun dalam jangka panjang dapat membebani karena mendorong utang pemerintah yang semakin meningkat (Samuelson \& Nordhaus, 2010).

Peran utang untuk menggerakkan perekonomian masih sering menjadi perdebatan. Utang memberikan dampak buruk pada pertumbuhan ekonomi jangka panjang serta berkorelasi negatif dengan pertumbuhan Produk Domestik Bruto per kapita (Checherita \& Rother, 2010), meskipun dalam jangka pendek memberikan efek positif dan tergantung dari kondisi masing-masing negara (Gomez-Puig \& Sosvilla-Rivero, 2017). Utang pemerintah tidak memengaruhi pertumbuhan ekonomi (Lartey, Musah, Okyere, \& Yusif, 2018). Walaupun terdapat hubungan jangka panjang antara utang pemerintah dengan pertumbuhan ekonomi, namun tingkat utang maksimal harus tetap dibatasi (Daud, 2016). Akhirnya, keberhasilan suatu negara menerapkan kebijakan fiskal dan meningkatkan utang tergantung dari komitmen dan fleksibilitas penerapan kebijakan itu sendiri (Yared, 2019).

\section{B. SBSN Sebagai Instrumen Pembiayaan Pemerintah}

Utang pemerintah saat ini didominasi oleh SBN. Sebelum krisis ekonomi tahun 1998, utang pemerintah Indonesia didominasi oleh utang berupa pinjaman yang bersumber dari luar negeri. Krisis ekonomi membuat pemerintah menanggung beban yang tinggi karena melemahnya nilai tukar rupiah terhadap US dolar. Efek positif dari dampak krisis ekonomi tersebut ialah dimulainya pengelolaan keuangan negara dengan lebih cermat dan hati-hati. Paket Undang-undang keuangan negara diterbitkan untuk membenahi tata kelola keuangan negara.

Strategi pemerintah dalam pembiayaan APBN bergeser dari pinjaman menjadi SBN setelah krisis ekonomi tahun 1998. Undang-undang yang mengatur mengenai SUN diterbitkan pada tahun 2002 sebagai landasan hukum pengelolaan SBN. SBSN atau lebih dikenal dengan sebutan Sukuk merupakan salah satu instrumen pembiayaan berupa SBN. Secara etimologis, sukuk berasal dari bahasa Arab, yaitu bentuk jamak dari Sakk yang berarti dokumen/lembaran kontrak yang serupa dengan sertifikat atau note (Hariyanto, 2017). Aturan standar penerbitan sukuk di dunia internasional mengacu pada The Accounting and Auditing Organization for Islamic Finance and Institution (AAOIFI).

Pasar keuangan syariah merupakan pasar yang sangat potensial untuk dikembangkan di Indonesia. Pertumbuhan pasar keuangan syariah yang salah satunya berupa SBSN tumbuh dengan cepat di Indonesia (Fatah, 2011). Indonesia merupakan negara dengan penduduk muslim terbesar di dunia. Peningkatan kesadaran masyarakat terutama muslim untuk bertransaksi keuangan secara syariah membuat pasar SBSN dalam negeri masih sangat terbuka. Bagi pemerintah, SBSN merupakan instrumen pembiayaan yang fleksibel dengan tingkat risiko yang terkendali. Hal ini bertujuan untuk menjaga kesinambungan 
fiskal dan pembiayaan dengan biaya yang rendah sekaligus mendukung pendalaman pasar keuangan domestik.

\section{METODE PENELITIAN}

Metodologi yang digunakan dalam penelitian ini ialah metode analisis kualitatif deskriptif. Penelitian kualitatif merupakan metode untuk mengeksplorasi dan memahami makna yang berasal dari masalah sosial atau kemanusiaan (Creswell, 2014). Instrumen penelitian kualitatif ialah peneliti itu sendiri, serta bertujuan untuk mendapatkan data yang mendalam dan mengandung makna (Sugiyono, 2008).

Analisis kualitatif dilakukan untuk mengolah data yang ada menjadi data sistematis, terstruktur dan mempunyai makna. Analisis deskriptif dilakukan dengan cara menelaah teori, informasi, dan data melalui studi literatur dari buku, publikasi ilmiah maupun peraturan perundangan. Data yang digunakan merupakan data sekunder yang berasal dari laporan pelaksanaan proyek PBS pada Kementerian Agama antara tahun 2013-2019. Laporan pelaksanaan proyek tersebut berupa pagu dan realisasi proyek, baik yang diperoleh dari aplikasi SPAN maupun laporan pelaksanaan PBS yang disampaikan Kementerian Agama ke Kementerian Keuangan.

Selanjutnya, data sekunder tersebut dikonfirmasi dengan data hasil wawancara dengan pengelola proyek PBS di Kementerian Agama, dan Kementerian Keuangan. Kementerian Agama dipilih karena merupakan Kementerian dengan jumlah satuan kerja (satker) pengelola proyek PBS yang paling banyak setiap tahun. Satker yang bervariasi diharapkan dapat memberikan informasi yang beragam dan analisis permasalahan yang mendalam. Kementerian Keuangan dalam hal ini berperan sebagai unit yang menerbitkan SBSN sebagai sumber pembiayaan bagi PBS dan sekaligus sebagai unit yang melakukan pemantauan dan evaluasi atas pelaksanaan proyek PBS pada Kementerian/Lembaga.

\section{HASIL PENELITIAN}

\section{A. Perkembangan dan Outstanding Utang berupa SBN}

SBN merupakan instrumen pembiayaan yang dianggap lebih baik daripada pinjaman. Kesediaan untuk memberikan pinjaman terutama berupa pinjaman luar negeri, tentu tidak dapat dilepaskan dari adanya kepentingan dari pihak pemberi pinjaman. Sedangkan utang yang berbentuk SBN akan lebih terbebas dari intervensi oleh investor. Dari sisi teknis, tingkat bunga SBN yang mengikuti perkembangan pasar membuatnya lebih fleksibel daripada tingkat bunga pinjaman sehingga pemerintah dapat dengan mudah mengelola portofolio utangnya sesuai dengan kondisi pasar dan perekonomian.

Jumlah outstanding utang pemerintah di akhir tahun 2019 ialah sebesar 4.779 triliun rupiah. Dari jumlah itu, nominal utang yang bersumber dari SBN tercatat sebesar 4.014 triliun rupiah atau sekitar 84 persen. Utang pemerintah yang bersumber dari SBSN tercatat sebesar 15,5 persen atau sekitar 740 triliun rupiah.

Gambar 1. Outstanding utang pemerintah 


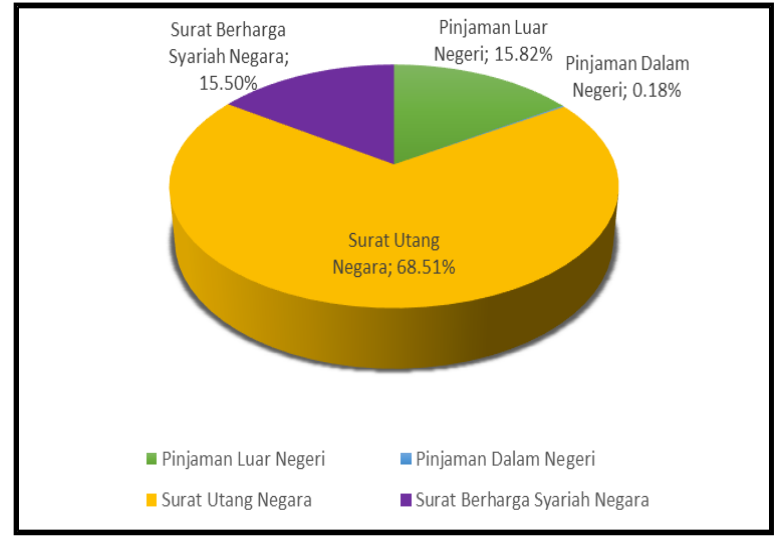

(Sumber: Kemenkeu, diolah).

Pembiayaan APBN melalui utang terutama surat berharga negara terus meningkat setiap tahun. Peningkatan defisit anggaran untuk memenuhi kebutuhan pembangunan ditambah dengan keterbatasan sumber pendapatan negara membuat utang masih menjadi tumpuan sebagai sumber pembiayaan APBN. Outstanding pembiayaan melalui SBN dapat dilihat pada Grafik 1.

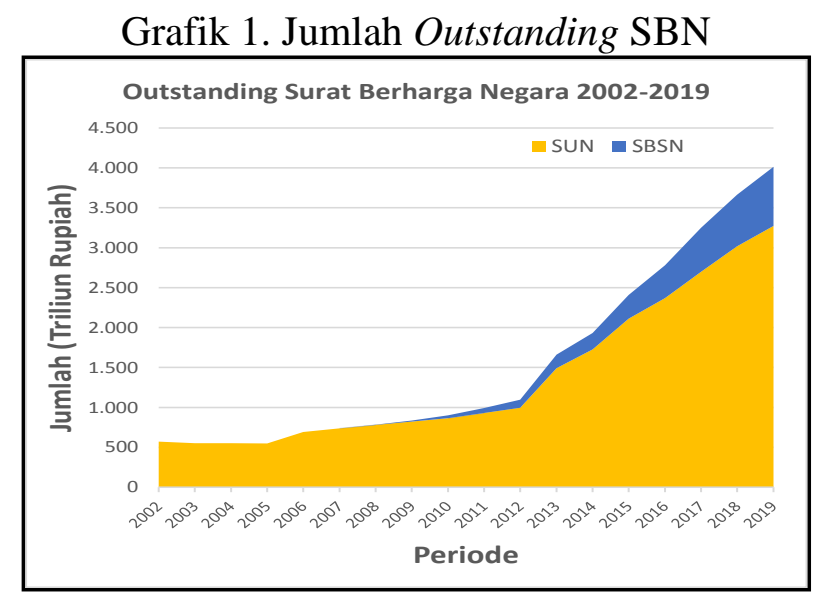

(Sumber:Kemenkeu, diolah).

\section{B. SBSN untuk Pembiayaan Proyek}

Pembangunan infrastruktur menjadi fokus pemerintah selama beberapa tahun terakhir. Kebutuhan pembiayaan proyek-proyek infrastruktur dalam kurun waktu 5 tahun terakhir ditaksir sekitar 5.000 triliun rupiah. Hal tersebut tentu tidak mungkin dapat dipenuhi semata-mata dari anggaran belanja K/L. Keterbatasan sumber dana APBN membuat pemerintah harus mencari cara untuk tetap dapat melaksanakan pembangunan infrastruktur dan salah satu alternatifnya ialah melalui pembiayaan atau utang.

PBS merupakan langkah awal transparansi pemanfaatan utang. Melalui proyek yang langsung terkoneksi dengan sumber pembiayaan, publik akan mendapatkan informasi yang jelas mengenai pemanfaatan utang yang dilakukan pemerintah. Selain itu, PBS merupakan salah satu alternatif pembiayaan proyek yang potensial karena sumbernya masih sangat luas untuk dikembangkan. 
Outstanding utang yang bersumber dari SBN sebesar 4.014 triliun rupiah. Akan tetapi, komposisi PBS untuk pembiayaan proyek hanya sebesar 414 triliun rupiah atau hanya 10 persen dari total outstanding SBN pemerintah. Hal ini menunjukkan bahwa pembiayaan proyek yang terkait langsung dengan SBN masih sangat terbatas. Permintaan kebutuhan tentang transparansi dan akuntabilitas utang oleh masyarakat membuat pemerintah harus dapat menjelaskan secara jelas mengenai pemanfaatan utang tersebut.

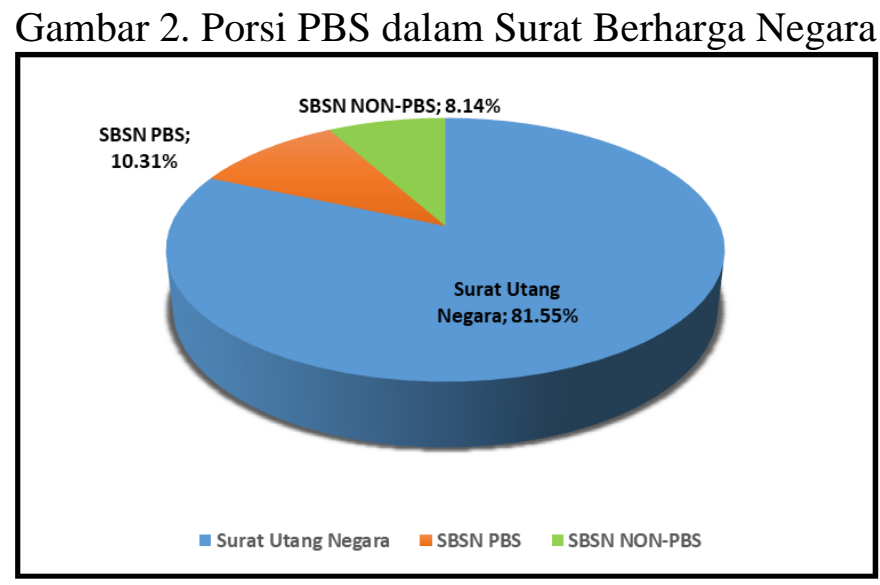

(Sumber: Kemenkeu, diolah)

Proyek yang dibiayai PBS diusulkan oleh Kementerian/Lembaga teknis untuk dinilai kelayakannya oleh Kementerian PPN/Bappenas sebelum disampaikan kepada Kementerian Keuangan dan Kementerian/Lembaga teknis dalam bentuk dokumen daftar prioritas proyek yang dibiayai PBS. Daftar prioritas proyek ini akan menjadi dasar alokasi anggaran bagi Kementerian/Lembaga untuk dianggarkan dalam APBN/APBNP.

Tabel 1. Pagu dan Realisasi PBS 2013-2019

\begin{tabular}{|ccrrr|}
\hline Tahun & $\begin{array}{c}\text { Jumlah K/L } \\
\text { Pelaksana } \\
\text { Proyek }\end{array}$ & $\begin{array}{c}\text { Pagu PBS } \\
\text { (miliar) }\end{array}$ & \multicolumn{1}{c|}{$\begin{array}{c}\text { Realisasi } \\
\text { (miliar) }\end{array}$} & $\begin{array}{c}\text { Persentase } \\
\text { Realisasi }\end{array}$ \\
\hline 2013 & 1 & 800,00 & 777,80 & $97,23 \%$ \\
2014 & 2 & $1.571,00$ & $1.156,43$ & $73,61 \%$ \\
2015 & 3 & $7.135,63$ & $4.850,98$ & $67,98 \%$ \\
2016 & 3 & $13.677,20$ & $9.929,36$ & $72,60 \%$ \\
2017 & 3 & $20.161,25$ & $17.026,33$ & $84,45 \%$ \\
2018 & 7 & $24.984,37$ & $19.935,07$ & $79,79 \%$ \\
$2019 *$ & 7 & $33.466,90$ & $25.720,89$ & $76,85 \%$ \\
*data per 31 Desember 2019 & & & \\
\hline
\end{tabular}

Proyek yang dibiayai melalui PBS terus meningkat setiap tahun sesuai dengan kebutuhan dan usulan Kementerian/Lembaga. Secara bertahap, pagu pembiayaan proyek melalui PBS terus meningkat dari 0,8 triliun rupiah di tahun 2013 menjadi 33 triliun di tahun 2019. Pagu PBS tersebut digunakan untuk membiayai proyek di tujuh 
Kementerian/Lembaga antara lain Kementerian Perhubungan, Kementerian Pekerjaan Umum dan Perumahan Rakyat, Kementerian Agama, Kementerian Riset Teknologi dan Pendidikan Tinggi, Kementerian Kehutanan dan Lingkungan Hidup, Badan Standarisasi Nasional, dan Lembaga Ilmu Pengetahuan Indonesia.

Pembiayaan melalui utang tidak dapat dipisahkan dengan konsep value for money. Setiap obligasi negara yang diterbitkan, baik itu berupa SUN maupun SBSN harus dilakukan dengan cermat dan sesuai dengan kebutuhan. Utang pemerintah harus dilakukan dengan cara yang paling efektif dan efisien. Biaya yang muncul dalam mekanisme pembiayaan membuat strategi pembiayaan pemerintah harus ditetapkan dengan cermat dan tepat. Dalam hal ini diperlukan pemantauan dan evaluasi yang efektif, karena inefektifitas dan inefisiensi pemantauan dan evaluasi berisiko menimbulkan tambahan biaya utang yang dapat membebani keuangan negara.

\section{Pembiayaan Proyek Melalui skema PBS di Kementerian Agama}

Perencanaan merupakan tahap yang krusial dalam manajemen. Keberhasilan suatu program sangat ditentukan oleh kualitas perencanaan. Perencanaan yang baik akan memberikan panduan bagi pelaksana program untuk mencapai tujuan yang ditetapkan.

Kementerian Agama mendapatkan alokasi dana proyek PBS sejak tahun 2014. Selama kurun waktu 6 tahun, peningkatan nominal proyek yang dibiayai PBS untuk Kementerian Agama meningkat sangat signifikan dari 200 miliar rupiah menjadi hampir sekitar 3 triliun rupiah. Jumlah lokasi pelaksana proyek pun meningkat dari 4 lokasi/satker menjadi 318 lokasi di tahun 2019. Dana PBS di Kementerian Agama digunakan untuk membiayai proyek pembangunan gedung kantor urusan agama, gedung madrasah dan universitas, serta gedung asrama haji dan fasilitas pendukungnya.

Proses pelaksanaan proyek yang dibiayai melalui PBS dimulai dengan adanya proyeksi kebutuhan pendanaan secara periodik yang disampaikan oleh Kementerian/Lembaga selaku pelaksana proyek kepada Kementerian Keuangan. Proyeksi kebutuhan dana tersebut menjadi dasar penerbitan SBSN-PBS untuk membiayai proyek. Setelah dana tersedia di kas negara, pelaksana proyek dapat mengajukan pembayaran atas pelaksanaan proyek sesuai progres pekerjaan.

Tabel 2. Pagu dan Realisasi PBS Kementerian Agama Tahun 2014-2019

\begin{tabular}{|cccrr|}
\hline Tahun & $\begin{array}{c}\text { Jumlah } \\
\text { Lokasi } \\
\text { Pelaksana } \\
\text { Proyek }\end{array}$ & $\begin{array}{c}\text { Pagu PBS } \\
\text { (miliar) }\end{array}$ & $\begin{array}{c}\text { Realisasi } \\
\text { (miliar) }\end{array}$ & $\begin{array}{c}\text { Persentase } \\
\text { Realisasi }\end{array}$ \\
\hline & & & & \\
2014 & 4 & 200,00 & 195,94 & $97,97 \%$ \\
2015 & 34 & 675,33 & 512,42 & $75,88 \%$ \\
2016 & 136 & $1.467,90$ & $1.377,21$ & $93,82 \%$ \\
2017 & 192 & $1.861,59$ & $1.658,34$ & $89,08 \%$ \\
2018 & 256 & $2.355,05$ & $2.032,56$ & $86,31 \%$ \\
$2019 *$ & 318 & $2.990,71$ & $2.202,21$ & $73,64 \%$ \\
*data per 31 Desember 2019 & & & \\
\hline
\end{tabular}

(Sumber: Kemenkeu, diolah)

Faktanya, meskipun proyeksi kebutuhan dana dalam bentuk rencana penarikan dana disampaikan oleh satker Kementerian/Lembaga pelaksana proyek secara periodik, 
realisasi penarikan yang dilakukan belum dapat dilaksanakan sesuai dengan jadwal yang ditetapkan. Akibatnya, terjadi pengendapan dana (idle cash) di kas negara yang disebabkan karena keterlambatan dan permasalahan pada saat pelaksanaan proyek.

Realisasi pencairan dana yang digunakan untuk membiayai proyek PBS tidak pernah mencapai target. Realisasi penarikan bahkan semakin menurun dalam kurun waktu 3 tahun terakhir. Hal ini kurang bagus dari sisi perencanaan karena dana yang digunakan untuk membiayai proyek tersebut berasal dari utang berupa Sukuk. Dengan demikian, pelaksanaan proyek tidak sesuai dengan perencanaan yang telah ditetapkan.

Permasalahan yang menghambat pelaksanaan proyek PBS, berdasarkan wawancara dengan satker pengelola proyek di Kementerian Agama disebabkan karena kendala pada tahap pengadaan. Ketentuan mengenai mekanisme pengadaan barang/jasa dan prosedur lelang yang cukup panjang membuat satker Kementerian/Lembaga kesulitan melewati tahap ini. Kurangnya kemampuan sumber daya manusia pada masing-masing satker yang memiliki pengetahuan dan penguasaan mekanisme pengadaan barang/jasa membuat proses pengadaan harus dilakukan oleh pihak Dinas Provinsi sehingga membutuhkan rantai birokrasi yang panjang.

Permasalahan lain yang sering menjadi kendala ialah kemampuan kontraktor pelaksana proyek yang terbatas. Proyek pembangunan infrastruktur melalui PBS terutama proyek yang nilainya tidak terlalu besar seperti pembangunan gedung KUA memang diutamakan untuk kontraktor dengan skala usaha menengah. Hal ini menyebabkan sering terjadi hambatan pelaksanaan pembangunan karena kontraktor tidak memiliki sisa dana untuk melanjutkan pembangunan. Padahal, pengajuan pembayaran terhadap kontraktor baru dapat dilakukan setelah kontraktor menyelesaikan progres pembangunan fisik proyek sesuai dengan ketentuan. Hal ini juga cukup menyulitkan bagi satker pengelola proyek di daerah.

Proyek yang diusulkan oleh Kementerian/Lembaga merupakan proyek pembangunan infrastruktur yang berupa belanja modal, baik untuk pembangunan gedung, maupun sarana dan prasarana lainnya. Keberhasilan proyek yang dibiayai melalui PBS saat ini cenderung hanya dinilai berdasarkan output, berupa jumlah unit gedung, bangunan, maupun sarana dan prasarana yang dibangun. Padahal idealnya, keberhasilan tersebut diukur dari dampak yang dihasilkan melalui proyek tersebut.

Keberhasilan pembangunan gedung KUA misalnya, seharusnya bukan diukur dari kuantitas gedung yang telah berdiri, akan tetapi diukur dari peningkatan kelancaran dan kualitas pelayanan oleh KUA tersebut setelah memiliki gedung yang baru. Evaluasi atas dampak pelaksanaan proyek tersebut belum dilakukan oleh Kementerian/ Lembaga.

\section{KESIMPULAN}

Kebutuhan mengenai transparansi utang pemerintah muncul karena adanya peningkatan pemahaman masyarakat terhadap pengelolaan keuangan negara. Isu mengenai utang selalu menarik untuk dibahas dan merupakan konsekuensi atas pembiayaan APBN yang dilakukan oleh pemerintah.

Dalam kurun waktu beberapa tahun terakhir, SBN menjadi instrumen utama pemerintah dalam memenuhi kebutuhan pembiayaan. Selain karena lebih fleksibel dan efisien dari sisi biaya jika dibandingkan dengan pinjaman, pembiayaan melalui SBN juga lebih aman dari risiko campur tangan pihak investor. Sumber pembiayaan dari pinjaman 
tentu tidak dapat dilepaskan dari kepentingan pemberi pinjaman sesuai dengan motivasi pemberi pinjaman tersebut.

PBS merupakan instrumen yang potensial dan sangat terbuka untuk dikembangkan karena pasar yang sangat luas. Penduduk muslim Indonesia merupakan yang terbesar di dunia serta mulai munculnya kesadaran untuk melakukan transaksi keuangan sesuai syariah menjadi keuntungan dalam pengembangan pasar terutama SBSN domestik. Terlebih lagi, pembiayaan pembangunan proyek infrastruktur masih dibutuhkan dalam jangka waktu beberapa tahun ke depan.

Pelaksanaan proyek PBS yang dilakukan oleh Kementerian/Lembaga masih mengalami beberapa kendala. Permasalahan dalam tahap lelang pengadaan menjadi permasalahan utama. Selain itu, keterbatasan finansial kontraktor yang berskala menengah dalam pelaksanaan pembangunan juga menjadi penyebab keterlambatan pelaksanaan proyek.

Kesiapan pelaksanaan proyek perlu dicantumkan dalam persyaratan pengajuan pembangunan proyek yang dibiayai PBS untuk meningkatkan efektifitas pelaksanaan proyek. Sanksi yang tegas terhadap kontraktor atau penyedia barang/jasa yang tidak mampu memenuhi kewajiban dalam kontrak pengadaan juga perlu ditegakkan. Penyediaan jaminan penyelesaian pekerjaan mungkin perlu dipertimbangkan agar pelaksanaan proyek dapat terlaksana tepat waktu dan sesuai dengan rencana.

Lebih jauh lagi, penilaian kinerja proyek infrastruktur yang dibiayai dari SBSN-PBS masih terhenti pada pencapaian output berupa jumlah gedung, bangunan, atau sarana dan prasarana yang dibangun. Seharusnya, pembangunan infrastruktur yang bersumber dari SBSN-PBS pada beberapa Kementerian/Lembaga tersebut perlu memperhatikan outcomes dan impact sehingga lebih terukur manfaatnya kepada masyarakat.

\section{IMPLIKASI DAN KETERBATASAN}

Penelitian ini menggunakan data yang dikelola oleh Kementerian Keuangan. Metodologi yang digunakan ialah analisis kualitatif deskriptif dengan menganalisis data yang ada, baik berupa data SBN, pagu anggaran PBS, maupun realisasi anggaran PBS yang dilaksanakan oleh Kementerian/Lembaga. Metodologi yang digunakan mungkin belum dapat menangkap seluruh permasalahan yang terjadi di lapangan. Penelitian secara lebih komprehensif pada seluruh Kementerian/ Lembaga yang menggunakan skema PBS akan meningkatkan akurasi data dan sebaran permasalahan, sehingga dapat lebih memberikan gambaran yang menyeluruh dan akurat.

\section{DAFTAR PUSTAKA}

BARRO, R. J. (1989). THE RICARDIAN APPROACH TO BUDGET DEFICITS . JOURNAL OF ECONOMIC PERSPECTIVES, VOLUME 3, NUMBER 2, 37-54.

Beik, I. S. (2011). Memperkuat Peran Sukuk Negara Dalam Pembangunan Ekonomi Indonesia. Jurnal Ekonomi Islam Al-Infaq, Vol. 2 No. 2, 65-72.

Checherita, C., \& Rother, P. (2010, August 2010). The Impact of High And Growing Government Debt On Economic Growth: An Empirical Investigation For The Euro Area. European Central Bank No.1237, pp. 1-40. 
Creswell, J. W. (2014). Research Design: Qualitative, Quantitative and Mixed Methods Approaches, 4th Edition. . California: SAGE Publication, Inc.

Daud, S. N. (2016). The Real Effect of Government Debt: Evidence from the Malaysian Economy. Journal of Economic Cooperation and Development, 57-86.

Fatah, D. A. (2011). Perkembangan Obligasi Syariah (Sukuk) di Indonesia: Analisis Peluang dan Tantangan. AL- 'ADALAH Vol. X, No. 1, 35-46.

Gomez-Puig, M., \& Sosvilla-Rivero, S. (2017, 2017/15 -). Public debt and economic growth: Further evidence for the euro area. Research Institute of Applied Economics, pp. $1-41$.

Hariyanto, E. (2017). Mengenal Sukuk Negara: Instrumen Pembiayaan APBN dan Sarana Investasi Masyarakat. Yogyakarta: Gava Media.

IMF. (2014). Revised Guidelines for Public Debt Management. Washington DC.: IMF. Indonesia, R. (2011, Februari). Peraturan Pemerintah Republik Indonesia Nomor 10 Tahun 2011 Tentang. Jakarta: Republik Indonesia.

Lartey, E. Y., Musah, A., Okyere, B., \& Yusif, A.-N. (2018). Public Debt and Economic Growth: Evidence from Africa. International Journal of Economics and Financial Issues, $35-45$.

Nasrullah, A. (2015). Studi Surat Berharga Negara: Analisis Komparatif Sukuk Negara Dengan Obligasi Negara Dalam Pembiayaan Defisit APBN. JURNAL LENTERA: Kajian Keagamaan, Keilmuan dan Teknologi, Volume 1, Nomor 2,.

Nopijantoro, W. (2017). Surat Berharga Syariah Negara Project Based Sukuk (SBSNPBS): Sebuah Instrumen Alternatif Partisipasi Publik Dalam Pembiayaan Infrastruktur. Substansi, Vol 1, No. 2, 390-406.

Pribadi, Y. (2017). Studi Utang Pemerintah sebagai Pembiayaan APBN Tahun 20002016. Jurnal Akuntansi Bisnis dan Sistem Informasi Vol.22, 1-11.

Pribadi, Y. (2019). Peran Pemantauan dan Evaluasi untuk Meningkatkan Efektifitas dan Efisiensi Pelaksanaan Proyek/Kegiatan yang Dibiayai melalui Pinjaman. Jurnal BPPK Vol.12 No.2, 114-137.

RI. (2002). Undang-Undang Nomor 24 Tahun 2002. Surat Utang Negara. Jakarta. RI. (2008). Undang-Undang Nomor 19 Tahun 2008. Surat Berharga Syariah Negara. Jakarta.

RI. (2011). Peraturan Pemerintah Nomor 10 Tahun 2011. Tata Cara Pengadaan Pinjaman Luar Negeri Dan Penerimaan Hibah. Jakarta.

Samuelson, P. A., \& Nordhaus, W. D. (2010). Economics Nineteenth Edition. New York: McGraw-Hill/Irwin.

Skousen, M. (2016). Sejarah Pemikiran Ekonomi: Sang Maestro Teori-teori Ekonomi Modern (Terjemahan). Jakarta: Prenada Media Group.

Sugiyono. (2008). Metode Penelitian Bisnis. Bandung: Alfabeta.

Yared, P. (2019). Rising Government Debt: Causes and Solutions for a Decades-Old Trend. Journal of Economic Perspectives, Volume 3, Number 2, 115-140. 